\title{
Propidium-Based Polyamine Ligands as Potent Inhibitors of Acetylcholinesterase and
}

\section{Acetylcholinesterase-Induced Amyloid- $\beta$ Aggregation}

Maria Laura Bolognesi, ${ }^{*}$ Vincenza Andrisano, Manuela Bartolini, Rita Banzi and Carlo Melchiorre Alma Mater Studiorum, University of Bologna, Department of Pharmaceutical Sciences, Via Belmeloro, 6, 40126, Bologna, Italy

\section{Supporting Information}

Contents of SI: Contains experimental details for the synthesis and for the determination of the biological activity, spectra data and elemental analysis data for all new compounds.

"To whom correspondence should be addressed. Phone: +39-051-2099700. Fax: +39-051-2099734. E-mail: MLB, marialaura.bolognesi@unibo.it or CM, carlo.melchiorre@unibo.it 


\section{Experimental Section}

\section{Chemistry}

Melting points were taken in glass capillary tubes on a Büchi SMP-20 apparatus and are uncorrected. IR and direct infusion ESI-MS spectra were recorded on Nicolet Avatar 320 and Waters Micromass ZQ 4000 apparatus. ${ }^{1} \mathrm{H}$ NMR experiments were recorded on Varian VXR 200 and $300 \mathrm{MHz}$ instruments. Chemical shifts are reported in parts per million (ppm) relative to tetramethylsilane (TMS), and spin multiplicities are given as s (singlet), d (doublet), $\mathrm{t}$ (triplet), or $\mathrm{m}$ (multiplet). Although the IR spectra data are not included (because of the lack of unusual features), they were obtained for all compounds reported and were consistent with the assigned structures. When the elemental analysis is not included, crude compounds were used in the next step without further purification. Chromatographic separations were performed on silica gel columns by flash (Kieselgel 40, 0.040-0.063 mm; Merck) or gravity column (Kieselgel 60, 0.063-0.200 mm; Merck) chromatography. Compounds were named following IUPAC rules as applied by Beilstein-Institut AutoNom (version 2.1), a PC integrated software package for systematic names in organic chemistry.

N1-[3-(1,2,3,4-Tetrahydro-acridin-9-ylamino)-propyl]-propane-1,3-diamine (7). N1-(3aminopropyl)-propane-1,3-diamine $(2.9 \mathrm{~mL}, 20.7 \mathrm{mmol})$ was added together with a catalytic amount of KI to a solution of $6(0.15 \mathrm{~g}, 0.69 \mathrm{mmol})$ in 1-pentanol $(3.5 \mathrm{~mL})$. The reaction mixture was then heated at $160{ }^{\circ} \mathrm{C}$ for $24 \mathrm{~h}$. After cooling to room temperature, the reaction mixture was diluted with water $(10 \mathrm{~mL})$ and extracted with $\mathrm{CH}_{2} \mathrm{Cl}_{2}(2 \times 40 \mathrm{~mL})$. The organic phases were dried and evaporated to give a residue that was purified by flash chromatography. Elution with a step gradient system of $\mathrm{CH}_{2} \mathrm{Cl}_{2} / \mathrm{MeOH} /$ aqueous $28 \%$ ammonia (8/2/0.2 to $\left.7 / 3.5 / 0.35\right)$ afforded 7 as a clear oil: 42\% yield; ${ }^{1} \mathrm{H}$ NMR (300 MHz, $\left.\mathrm{CDCl}_{3}\right): \delta 8.00(\mathrm{~d}, 1 \mathrm{H}, \operatorname{Ar} H), 7.90(\mathrm{~d}, 1 \mathrm{H}, \operatorname{Ar} H), 7.55(\mathrm{t}$, 1H, ArH), $7.25(\mathrm{t}, 1 \mathrm{H}, \mathrm{ArH}), 3.60\left(\mathrm{t}, 2 \mathrm{H}, \mathrm{Ar}-\mathrm{NHCH}_{2}\right), 3.00-3.15\left(\mathrm{~m}, 2 \mathrm{H}, \mathrm{N}=\mathrm{C}-\mathrm{CH}_{2}\right), 2.60-2.85$ (complex m, 8H, $\mathrm{ArCH}_{2}+\mathrm{NHCH}_{2}+\mathrm{CH}_{2} \mathrm{NH}_{2}$ ), 1.50-2.00 (complex m, 8H $+3 \mathrm{H}$ exchangeable with $\mathrm{D}_{2} \mathrm{O}, \mathrm{CH}_{2} \mathrm{CH}_{2} \mathrm{CH}_{2}+\mathrm{NH}+\mathrm{NH}_{2}$ ). 


\section{3,8-Diamino-6-phenyl-5-(3-\{3-[3-(1,2,3,4-tetrahydro-acridin-9-ylamino)-propylamino]-}

propylamino\}-propyl)-phenanthridinium Chloride Trihydrocloride (4). Compound 8 (0.07 g, $0.12 \mathrm{mmol})$ was added to a solution of $7(0.09 \mathrm{~g}, 0.29 \mathrm{mmol})$ in $\mathrm{MeOH}(4 \mathrm{~mL})$ and the resulting solution was stirred under reflux for $7 \mathrm{~h}$. After pouring the cooled mixture into water $\mathrm{MeOH}$ was evaporated to afford a yellow solid, which was washed with water and then dried (ESI-MS $(\mathrm{m} / \mathrm{z})$ : $\left.362\left(\mathrm{M}+\mathrm{H}^{+} / 2\right)\right)$. The crude material, dissolved in $\mathrm{MeOH}(4 \mathrm{~mL})$, was added of $12 \mathrm{~N} \mathrm{HCl}(0.4 \mathrm{~mL})$ and the resulting mixture was refluxed under stirring for $2 \mathrm{~h}$. After cooling, ether was added to precipitate 4 as hydrochloride salt (purple solid): $20 \%$ yield; mp $248{ }^{\circ} \mathrm{C}$ (dec.); ${ }^{1} \mathrm{H}$ NMR $(200 \mathrm{MHz}$, $\left.\mathrm{CD}_{3} \mathrm{OD}\right): \delta 8.50-8.65(\mathrm{~m}, 2 \mathrm{H}), 8.79-8.83(\mathrm{~m}, 2 \mathrm{H}), 7.50-8.02(\mathrm{~m}, 10 \mathrm{H}), 7.35(\mathrm{~s}, 1 \mathrm{H}), 4.75(\mathrm{t}, 2 \mathrm{H})$, 4.05-4.14 (m, 2H), 2.82-3.41 (complex m, 12H), 1.91-2.62 (complex m, 10H); ESI-MS (m/z): 320 $\left(\mathrm{M}+\mathrm{H}^{+} / 2\right)$. Calcd. for $\mathrm{C}_{41} \mathrm{H}_{51} \mathrm{Cl}_{4} \mathrm{~N}_{7}: \mathrm{C}$ 62.83, H 6.56, N 12.51. Found C 62.54, H 6.45, N 12.26.

\{3-[3-(2-Methoxy-benzylamino)-propylamino]-propyl\}-carbamic Acid tert-Butyl Ester (10). A mixture of N1-BOC-3,3'-iminodipropylamine 9 (Fluka) (4.6 g, $20.0 \mathrm{mmol}$ ), molecular sieves (3 $\AA$ ), and 2-methoxybenzaldehyde $(2.5 \mathrm{~mL}, 21.0 \mathrm{mmol})$ in EtOH $(100 \mathrm{~mL})$ was stirred for $30 \mathrm{~min}$ at room temperature, then $\mathrm{NaBH}_{4}(0.4 \mathrm{~g}, 10.5 \mathrm{mmol})$ was added, and the stirring was continued overnight. Following removal of molecular sieves, the solution was made acidic with $2 \mathrm{~N} \mathrm{KHSO}_{4}(4$ $\mathrm{mL})$. Removal of the solvent gave a residue that was dissolved in water $(40 \mathrm{~mL})$, then made basic with $2 \mathrm{~N} \mathrm{NaOH}$, and finally extracted with $\mathrm{CHCl}_{3}(3 \times 30 \mathrm{~mL})$. The organic phases were dried and evaporated to give a residue that was purified by flash chromatography. Elution with $\mathrm{CHCl}_{3} / \mathrm{MeOH} /$ aqueous $28 \%$ ammonia (8.2/1.8/0.18) gave $\mathbf{1 0}$ as an oil: $52 \%$ yield; ${ }^{1} \mathrm{H}$ NMR (300 $\left.\mathrm{MHz}, \mathrm{CDCl}_{3}\right): \delta$ 7.15-7.20 (m, 2H, ArH), 6.75-6.84 (m, 2H, ArH), 5.43 (br s, $1 \mathrm{H}$, exchangeable with $\left.\mathrm{D}_{2} \mathrm{O}, \mathrm{CONH}\right), 3.75\left(\mathrm{~s}, 3 \mathrm{H}, \mathrm{OCH}_{3}\right), 3.70\left(\mathrm{~s}, 2 \mathrm{H}, \mathrm{ArCH}_{2}\right), 3.01-3.20\left(\mathrm{~m}, 2 \mathrm{H}, \mathrm{CONHCH}_{2}\right), 2.52-$ $2.60\left(\mathrm{~m}, 6 \mathrm{H}, \mathrm{NHCH}_{2}\right), 1.45-1.65\left(\mathrm{~m}, 4 \mathrm{H}+2 \mathrm{H}\right.$ exchangeable with $\left.\mathrm{D}_{2} \mathrm{O}, \mathrm{CH}_{2} \mathrm{CH}_{2} \mathrm{CH}_{2}+\mathrm{NH}\right), 1.36(\mathrm{~s}$, $\left.9 \mathrm{H}, \mathrm{CH}_{3} \mathrm{C}\right)$.

[3-(\{3-[(2-Methoxy-benzyl)-methyl-amino]-propyl\}-methyl-amino)-propyl]-carbamic Acid tert-Butyl Ester (11). Formaldehyde (2.77 mL, $99.8 \mathrm{mmol}), \mathrm{NaBH}_{3} \mathrm{CN}(1.01 \mathrm{~g}, 16.1 \mathrm{mmol})$ and 
$\mathrm{CH}_{3} \mathrm{COOH}(0.69 \mathrm{~mL}, 11.97 \mathrm{mmol})$ were added to a solution of $\mathbf{1 0}(1.4 \mathrm{~g}, 3.99 \mathrm{mmol})$ in EtOH (40 $\mathrm{mL}$ ) and the resulting mixture was stirred overnight. After cooling, it was made basic with $40 \%$ aqueous $\mathrm{NaOH}$ and evaporated to give a residue that was partitioned between water and $\mathrm{CHCl}_{3}$. Removal of washed (brine) and dried organic phase gave 11 as an oil: 83\% yield; ${ }^{1} \mathrm{H}$ NMR (300 $\left.\mathrm{MHz}, \mathrm{CDCl}_{3}\right): \delta$ 7.20-7.35 (m, 2H, $\left.\mathrm{ArH}\right), 6.81-7.00(\mathrm{~m}, 2 \mathrm{H}, \mathrm{ArH}), 5.43$ (br s, 1H, exchangeable with $\left.\mathrm{D}_{2} \mathrm{O}, \mathrm{CONH}\right), 3.80\left(\mathrm{~s}, 3 \mathrm{H}, \mathrm{OCH}_{3}\right), 3.50\left(\mathrm{~s}, 2 \mathrm{H}, \mathrm{ArCH}_{2}\right), 3.22\left(\mathrm{t}, 2 \mathrm{H}, \mathrm{CONHCH}_{2}\right), 2.30-2.50$ (m, 6H, $\left.\mathrm{CH}_{3} \mathrm{NCH}_{2}\right), 2.21\left(\mathrm{~s}, 3 \mathrm{H}, \mathrm{NCH}_{3}\right), 2.19$ (s, 3H, $\left.\mathrm{NCH}_{3}\right), 1.60-1.80\left(\mathrm{~m}, 4 \mathrm{H}, \mathrm{CH}_{2} \mathrm{CH}_{2} \mathrm{CH}_{2}\right), 1.45$ $\left(\mathrm{s}, 9 \mathrm{H}, \mathrm{CH}_{3} \mathrm{C}\right)$.

N1-\{3-[(2-Methoxy-benzyl)-methyl-amino]-propyl\}-N1-methyl-propane-1,3-diamine (12). A solution of $11(0.27 \mathrm{~g}, 0.229 \mathrm{mmol})$ in $\mathrm{CHCl}_{3}(40 \mathrm{~mL})$ and $\mathrm{CF}_{3} \mathrm{COOH}(18 \mathrm{~mL})$ was stirred for $3 \mathrm{~h}$. Removal of the solvents gave a residue that was purified by flash chromatography. Elution with $\mathrm{CH}_{2} \mathrm{Cl}_{2} / \mathrm{MeOH}$ /aqueous $28 \%$ ammonia (9/1/0.1) afforded 12 as an oil: $65 \%$ yield; ${ }^{1} \mathrm{H}$ NMR (200 $\left.\mathrm{MHz}, \mathrm{CDCl}_{3}\right): \delta$ 7.20-7.40 (m, 2H, $\left.\mathrm{ArH}\right), 6.80-7.00(\mathrm{~m}, 2 \mathrm{H}, \mathrm{ArH}), 3.85\left(\mathrm{~s}, 3 \mathrm{H}, \mathrm{OCH}_{3}\right), 3.50(\mathrm{~s}, 2 \mathrm{H}$, $\left.\mathrm{ArCH}_{2}\right), 2.75\left(\mathrm{t}, 2 \mathrm{H}, \mathrm{CH}_{2} \mathrm{NH}_{2}\right), 2.35-2.50\left(\mathrm{~m}, 6 \mathrm{H}, \mathrm{CH}_{3} \mathrm{NCH}_{2}\right), 2.25\left(\mathrm{~s}, 6 \mathrm{H}, \mathrm{NCH}_{3}\right), 1.50-1.80(\mathrm{~m}, 4 \mathrm{H}$ $+2 \mathrm{H}$ exch with $\mathrm{D}_{2} \mathrm{O}, \mathrm{CH}_{2} \mathrm{CH}_{2} \mathrm{CH}_{2}+\mathrm{CH}_{2} \mathrm{NH}_{2}$ ).

3,8-Diamino-5-\{3-[3-(\{3-[(2-methoxy-benzyl)-methyl-amino]-propyl\}-methylamino)propylamino]-propyl\}-6-phenyl-phenanthridinium Chloride Trihydrocloride (5). It was synthesized as a foam from $\mathbf{8}$ and $\mathbf{1 2}$, following the procedure described for $4 .{ }^{1} \mathrm{H}$ NMR (300 MHz, $\left.\mathrm{CD}_{3} \mathrm{OD}\right): \delta 8.80-9.01(\mathrm{~m}, 2 \mathrm{H}), 7.79-7.82(\mathrm{~m}, 3 \mathrm{H}), 7.35-7.72(\mathrm{~m}, 7 \mathrm{H}), 7.00-7.20(\mathrm{~m}, 3 \mathrm{H}), 4.75(\mathrm{t}$, 2H), $4.42(\mathrm{~s}, 2 \mathrm{H}), 4.05-4.14(\mathrm{~m}, 2 \mathrm{H}), 3.98(\mathrm{~s}, 3 \mathrm{H}), 3.04-3.41$ (complex m, 10H), 2.12-2.60 (complex m, 6H); ESI-MS (m/z): $605\left(\mathrm{M}^{+}\right), 302\left(\mathrm{M}+\mathrm{H}^{+} / 2\right)$. Calcd. for $\mathrm{C}_{38} \mathrm{H}_{52} \mathrm{Cl}_{4} \mathrm{~N}_{6} \mathrm{O}: \mathrm{C} 60.80, \mathrm{H}$ 6.98, N 11.20. Found C 60.50, H 6.75, N 11.00.

\section{Biology}

Inhibition of AChE and BChE. The method of Ellman et al. was followed. Five different concentrations of each compound were used in order to obtain inhibition of AChE or BChE activity 
comprised between $20-80 \%$. The assay solution consisted of a $0.1 \mathrm{M}$ phosphate buffer $\mathrm{pH}$ 8.0, with the addition of $340 \mu \mathrm{M}$ 5,5'-dithio-bis(2-nitrobenzoic acid), $0.02 \mathrm{unit} / \mathrm{mL}$ of human recombinant $\mathrm{AChE}$ or human serum BChE (Sigma Chemical), and $550 \mu \mathrm{M}$ of substrate (acetylthiocholine iodide or butyrylthiocholine iodide). Test compounds were added to the assay solution and preincubated at $37{ }^{\circ} \mathrm{C}$ with the enzyme for $20 \mathrm{~min}$ followed by the addition of substrate. Assays were done with a blank containing all components except $\mathrm{AChE}$ or $\mathrm{BChE}$ in order to account for non-enzymatic reaction. The reaction rates were compared and the percent inhibition due to the presence of test compounds was calculated. Each concentration was analyzed in triplicate, and $\mathrm{IC}_{50}$ values were determined graphically from log concentration-inhibition curves.

Determination of Steady State Inhibition Constant. To obtain estimates of the competitive inhibition constant $K_{\mathrm{i}}$, reciprocal plots of $1 / \mathrm{V}$ versus $1 /[\mathrm{S}]$ were constructed at relatively low concentration of substrate (below $0.5 \mathrm{mM}$ ). The plots were assessed by a weighted least square analysis that assumed the variance of $\mathrm{V}$ to be a constant percentage of $\mathrm{V}$ for the entire data set. Slopes of these reciprocal plots were then plotted against the concentration of the inhibitors (range: $0-30 \mu \mathrm{M}$ for $2,0-2.0 \mathrm{nM}$ for 4 , and $0-2.0 \mu \mathrm{M}$ for 5) in a weighted analysis and $K_{\mathrm{i}}$ was determined as the ratio of the replot intercept to the replot slope.

Inhibition of $\mathbf{A C h E}$-induced $\mathbf{A} \boldsymbol{\beta}$ aggregation. Aliquots of $2 \mu \mathrm{L} \mathrm{A} \beta$ peptide, lyophilized from $2 \mathrm{mg} \mathrm{mL}^{-1}$ 1,1,1,3,3,3-hexafluoro-2-propanol solution and dissolved in DMSO, were incubated for $24 \mathrm{~h}$ at room temperature in $0.215 \mathrm{M}$ sodium phosphate buffer $(\mathrm{pH} 8.0)$ at a final concentration of $230 \mu \mathrm{M}$. For co-incubation experiments aliquots $(16 \mu \mathrm{L})$ of $\mathrm{AChE}$ (final concentration $2.30 \mu \mathrm{M}$, $\mathrm{A} \beta / \mathrm{AChE}$ molar ratio 100:1) and $\mathrm{AChE}$ in the presence of $2 \mu \mathrm{L}$ of the tested inhibitor in $0.215 \mathrm{M}$ sodium phosphate buffer $\mathrm{pH} 8.0$ solution (final inhibitors concentration ranging between 5 and 100 $\mu \mathrm{M})$ were added.

Blanks containing $\mathrm{A} \beta, \mathrm{AChE}$, and $\mathrm{A} \beta$ plus inhibitors at various concentrations, in $0.215 \mathrm{M}$ sodium phosphate buffer ( $\mathrm{pH} 8.0)$ were prepared. The final volume of each vial was $20 \mu \mathrm{L}$. Each assay was run in duplicate. To quantify amyloid fibril formation, the thioflavin $\mathrm{T}$ (ThT) 
fluorescence method was then applied. After dilution with glycine- $\mathrm{NaOH}$ buffer ( $\mathrm{pH} 8.5$ ), containing 1.5 $\mu \mathrm{M}$ ThT, the fluorescence intensities due to $\beta$-sheet conformation was monitored for $300 \mathrm{~s}$ at $\lambda_{\mathrm{em}}=490 \mathrm{~nm}\left(\lambda_{\mathrm{ex}}=446 \mathrm{~nm}\right)$. The percent inhibition of the AChE induced aggregation due to the presence of the test compound was calculated by the following expression: $100-\left(\mathrm{IF}_{\mathrm{i}} / \mathrm{IF}_{\mathrm{o}} \mathrm{x} 100\right)$ where $\mathrm{IF}_{\mathrm{i}}$ and $\mathrm{IF}_{\mathrm{o}}$ are the fluorescence intensities obtained for $\mathrm{A} \beta$ plus $\mathrm{AChE}$ in the presence and in the absence of inhibitor, respectively, minus the fluorescent intensities due to the respective blanks. Inhibition curves were obtained for each compound by plotting the percentage inhibition versus the logarithm of inhibitor concentration in the assay sample. The linear regression parameters were determined and the $\mathrm{IC}_{50}$ extrapolated, when possible (GraphPad Prism 3.0 GraphPad Software Inc.) 